\title{
Study of the effect of the opioid antagonist Naltrexone on acetic acid-induced enteritis in rats
}

\author{
Mahmoud Ahmed Zaffan, ${ }^{1}$ MSc, Ahmed Mohamed Labib, ${ }^{1}$ MD, Adel Ibrahim Abd Alaziz, ${ }^{1}$ MD.
}

\author{
* Corresponding Author: \\ Mahmoud Ahmed Zaffan \\ mahmoudzafan064@gmail.com
}

\section{Received for publication February 4, 2020; Accepted January 25, 2021; Published online January 25, 2021}

Copyright 2020 The Authors published by Al-Azhar University, Faculty of Medicine, Cairo, Egypt. All rights reserved. This an open-access article distributed under the legal terms, where it is permissible to download and share the work provided it is properly cited. The work cannot be changed in any way or used commercially.

doi: 10.21608/aimj.2021.23470.1126.

${ }^{l}$ Pharmacology Department, Faculty of Medicine, Al-Azhar University.

\begin{abstract}
Background: Crohn's disease is a transmural, relapsing inflammatory condition affecting the digestive tract. Opioid signaling was known to affect secretion and motility in the gut and may be implicated in the inflammatory cascade of Crohn's disease. Endogenous Opioid peptides modulate inflammatory cytokine production. Opioid antagonists have been shown to play a role in healing and repair of tissues.

Aim of the study: to detect the possible beneficial effects of opioid antagonist naltrexone in acetic acid-induced enteritis in rats.

Animals and Methods: Mature rats are allocated into 9 groups (6 rats each). Enteritis was induced by 2 trans-rectal injection of acetic acid $4 \%(2$ $\mathrm{mg} / \mathrm{kg})$. Salfasalazine $(500 \mathrm{mg} / \mathrm{kg} /$ day $)$, naltrexone $(0.05,0.5$ and one $\mathrm{mg} / \mathrm{kg} /$ day), and their combination were administered orally from day 1 to day 10. Disease activity index (DAI), biochemical parameters including serum levels of CRP and TNFa, macroscopic and microscopic pathological scores, and in vitro experimental motility studies were used to evaluate the effects of the tested drugs on normal as well as model groups.

Results: Induction of enteritis with acetic acid resulted in significant deterioration of DAI, significant elevation of the measured biochemical parameters, and significant deterioration of pathological scores. Treatment with sulfasalazine, low dose of naltrexone, high dose of naltrexone as well as treatment with combination of salfasalazine and naltrexone in both used doses resulted in significant improvement of all measured parameters. Also, Ach-induced contraction of isolated ileal segment showed significant decrease in untreated ones.

Conclusion: The results of the present study revealed that naltrexone has the potential to ameliorate the inflammatory response to acetic acid. So opioid antagonist.
\end{abstract}

Keywords: IMRT; High-Grade Gliomas; limited volumes. spinal.

Disclosure: The authors have no financial interest to declare in relation to the content of this article. The Article Processing Charge was paid for by the authors.

Authorship: All authors have a substantial contribution to the article.

\section{INTRODUCTION}

Enteritis is inflammation of small intestine caused by wide range of infectious and non-infectious agents. The disease may result from norovirus, rotavirus, campylobacter and giardia infection.

Crohn's disease, celiac disease, ulcerative colitis and radiation enteritis are the main non-infectious risk factors. Crohn's disease is known as an idiopathic, chronic gastrointestinal inflammatory disease which can impact any part of the tract, particularly the terminal ileum and colon. ${ }^{2}$

Crohn's disease starts as a focal inflammatory infiltrate accompanied by superficial mucosal ulceration across the crypts. The deep mucosal layers are later infiltrated by inflammatory cells and start to assemble onto noncaseating granulomas. The granulomas spread via all the intestinal wall layers as well as through the mesentery and regional lymph nodes. ${ }^{3}$ Significant variables are both hereditary vulnerability and environmental triggers. ${ }^{4}$

Patients with Crohn's disease often undergo cycles of symptomatic relapse and recovery. ${ }^{5}$ Manifested mainly by abdominal pain and diarrhea, that can be compounded by intestinal fistulization or obstruction, rectal bleeding, high temperature, weight loss, malnutrition, osteoporosis, vitamin deficiency, depression, and anxiety. ${ }^{6}$

There are no specific laboratory investigations for Crohn's disease diagnosis. In the diagnosis of Crohn's 
disease, endoscopic visualisation and biopsy are important. $^{7}$

Management of Crohn's disease depends primarily on hasting inflammation. In mild and moderate cases, Aminosalicylates (such as Sulfasalazine) may be used. In extreme and resistant cases, corticosteroids, immunomodulators such as Azathioprine, and Infliximab are used. ${ }^{8}$

Several studies have shown that immune cells can express $\mu, \mathrm{x}$, and $\delta$-opioid receptors. ${ }^{9}$ There is growing reports that opioid can control immune responses. Tcells and macrophages may be sensitised by opioid peptides as other pro-inflammatory stimuli. ${ }^{10}$ The signaling by opioid receptors expressed by intestinal immune cells has a major effect on the development of cytokines and inflammation of the intestine. ${ }^{11}$

The purpose of this study is to assess the impact of various graded doses of opioid antagonist "Naltrexone" alone or with Salfasalazine on the inflammatory process in acetic acid-induced enteritis in rats compared to Sulfasalazine alone. as standard drug.

\section{ANIMALS AND METHODS}

\section{Drugs used:}

Naltrexone (SIGMA pharmaceutical company, Egypt)was dissolved in distilled water and administered to rats in a dose $0.05 \mathrm{mg} / \mathrm{kg} /$ day and 0.5 $\mathrm{mg} / \mathrm{kg} /$ day and $1 \mathrm{mg} / \mathrm{kg} /$ day for 10 days. ${ }^{12}$

(Doses have been extrapolated by means of the Body Surface Area (BSA)-based dose translation formula. 13

Formula for Dose Translation Based on BSA

HED $(\mathbf{m g} / \mathbf{k g})=$ Animal dose $(\mathbf{m g} / \mathbf{k g})$ multiplied by $\frac{\text { Animal } \mathbf{K m}}{\text { Human } \mathbf{K m}}$

Sulfasalazine (Salazopyrin, Pfizer) $500 \mathrm{mg}$ tablets have been smashed and dissolved in distilled water and administered orally to rats at a dosage of 500 $\mathrm{mg} / \mathrm{kg} / \mathrm{d}$ by means of oral gavage. ${ }^{14}$

\section{Animals :}

Animals will be used Fifty four healthy white albino rats weighed $150-200 \mathrm{~g}$ supply by al-Nile Pharmaceutical Company from the animal house. At room temperature, rats were kept in stainless steel crates under a light/dark period of 12 hours. The study was in compliance with the guidelines for animal research..

The animals have been divided into nine groups. (6 each). Group 1: Normal rats serving as control, Group 2: received acetic acid $4 \% 2 \mathrm{ml}$ transrectal for 10 days. (Control group of acetic acid-induced enteritis),
Group 3: received acetic acid and Naltrexone in a dose $0.05 \mathrm{mg} / \mathrm{kg} /$ day for 10 days, Group 4: received acetic acid and Naltrexone in a dose $0.5 \mathrm{mg} / \mathrm{kg} /$ day for 10 days, Group 5: received acetic acid and Naltrexone (dose $1 \mathrm{mg} / \mathrm{kg} /$ day for 10 days $^{15}$, Group 6: received acetic acid and Sulfasalazine( dose of $500 \mathrm{mg} / \mathrm{kg} /$ day dissolved in $1 \mathrm{ml}$ water for 10 days), Group 7: received acetic acid, Naltrexone (dose of $0.05 \mathrm{mg} / \mathrm{kg} / \mathrm{day}$ and Sulfasalazine dose of $500 \mathrm{mg} / \mathrm{kg} /$ day for 10 days), Group 8: received acetic acid, Naltrexone (dose of 0.5 $\mathrm{mg} / \mathrm{kg} /$ day and Sulfasalazine dose of $500 \mathrm{mg} / \mathrm{kg} /$ day for 10 days) and Group 9: received acetic acid, Naltrexone (dose of $1 \mathrm{mg} / \mathrm{kg} /$ day and Sulfasalazine dose of $500 \mathrm{mg} / \mathrm{kg} /$ day for 10 days) .

Enteritis was induced by transrectal administration of $2 \mathrm{ml}$ acetic acid $4 \%$ through pediatric catheter as described by Yamada et al., 1993.15

\section{Assessment of intestinal inflammation:}

1. Disease activity index (DAI)

-Bodyweight changes:

Each rat's body weight was registered. On day one, body weight was assumed to be $100 \%$ weight and weight changes every day were calculated as a deviation from day one weight.

-Stool consistency:

Clinical inflammatory response characteristics were obtained via the accuracy of the follow-up stool. By placing the rats separately in cages without bedding, the stool consistency was rated. They have been kept in the cages until ample stool was released to maintain the consistency. A spatula then pulled the stool out and smeared a slice of cardboard with it.

Diarrhea presence and severity were scored on a scale of (0 to 3$).^{16}$

\begin{tabular}{|l|l|}
\hline 0 & Normal well-formed pellets \\
\hline 1 & Slight soft but well-formed \\
\hline 2 & Soft not formed \\
\hline 3 & Watery stool \\
\hline
\end{tabular}

Gross rectal bleeding was scored on a scale (0 to 3$).{ }^{16}$

\begin{tabular}{|c|l|}
\hline 0 & No traces of blood \\
\hline 1 & Specks of blood in stool \\
\hline 2 & Blood present in stool \\
\hline 3 & $\begin{array}{l}\text { Prominent blood in stool and or sticking } \\
\text { all around rectum. }\end{array}$ \\
\hline
\end{tabular}

2. Collection of blood samples:

From the retro-orbital venous plexus, venous samples were collected. At room temperature, the obtained blood samples were incubated until blood clotted and then centrifuged to separate the serum. Serum samples were tested for laboratory evaluation of C.reactive Protein (CRP) and tumor necrotic factor (TNF- $\alpha$ ) serum levels. 


\section{Pathological examination:}

Rats were slaughtered and the small intestine separated, held on an ice-cold tray, cleaned of fat and mesentery, then opened along the anti-mesenteric boundary, then longitudinal jejunum and ileum samples were collected and checked for signs of inflammation or ulceration. Segments were stored for histopathological examination and in-vitro studies.

\section{Macroscopic appearance:}

The intestinal mucosa graded on a scale from (0-6). ${ }^{14}$

\begin{tabular}{|l|l|}
\hline 0 & no macroscopic change \\
\hline 1 & Mucosal erythema at site \\
\hline 2 & Loss of mucosal integrity \\
\hline 3 & Lesions having diameter $\leq 2 \mathrm{~mm} \mathrm{no} \leq 5$ \\
\hline 4 & Lesions having diameter $\leq 2 \mathrm{~mm} \mathrm{no} \geq 5$ \\
\hline 5 & Lesions having diameter $\geq 2 \mathrm{~mm} \mathrm{no} \leq 5$ \\
\hline 6 & Lesions having diameter $\geq 2 \mathrm{~mm} \mathrm{no} \geq 5$ \\
\hline
\end{tabular}

\section{Statistical Analysis}

The mean \pm standard error $(\mathrm{X} \pm \mathrm{SE})$ was represented as the variability of the outcomes. By using the oneway analysis of variance (ANOVA) followed by Tukey's test as a post hoc analysis, statistical analysis of the difference among groups was conducted. The charts were created using the Microsoft Office XP 2010 Excel software. Degree of significance $(P>0.05$ $=$ insubstantial variations, $\mathrm{P}<0.05=$ substantial variations).

\section{RESULTS}

\begin{tabular}{|l|l|l|}
\hline \multicolumn{1}{|c|}{ Group } & $\begin{array}{c}\text { mean body } \\
\text { weight } \\
\text { (day1) }\end{array}$ & $\begin{array}{c}\text { mean body } \\
\text { weight } \\
\text { (day10) }\end{array}$ \\
\hline Normal Group 1 & $201 \pm 0.9$ & $201 \pm 0.9$ \\
\hline $\begin{array}{l}\text { Acetic acid model } \\
\text { Group 2 }\end{array}$ & $201 \pm 0.9$ & $162 \pm 0.8^{*}$ \\
\hline $\begin{array}{l}\text { Low dose Naltrexone } \\
\text { Group 3 (0.05mg) }\end{array}$ & $201 \pm 0.9$ & $198 \pm 0.9 \#$ \\
\hline $\begin{array}{l}\text { Medium dose Naltrexon } \\
\text { Group 4 (0.5mg) }\end{array}$ & $201 \pm 0.9$ & $199 \pm 0.9 \#$ \\
\hline $\begin{array}{l}\text { Hihg dose Naltrexon } \\
\text { Group 5 ( 1mg) }\end{array}$ & $201 \pm 0.9$ & $200 \pm 0.7 \#$ \\
\hline $\begin{array}{l}\text { A.acid+ Sulfasalazine } \\
\text { Group 6 }\end{array}$ & $201 \pm 0.9$ & $191 \pm 0.9 * \#$ \\
\hline $\begin{array}{l}\text { A.acid+ sulf+Low dose } \\
\text { Naltrexon Group 7 }\end{array}$ & $201 \pm 0.9$ & $194 \pm 0.9 \#$ \\
\hline $\begin{array}{l}\text { A.acid+ sulf +medium } \\
\text { dose Naltrexon Group 8 }\end{array}$ & $201 \pm 0.9$ & $200 \pm 0.9 \#$ \\
\hline $\begin{array}{l}\text { A.acid+Sulf+high dose } \\
\text { Naltrexone Group 9 }\end{array}$ & $201 \pm 0.9$ & $200 \pm 0.9 \#$ \\
\hline
\end{tabular}

Table 1: The mean body weight (Mean $\pm \mathrm{SE})$ in rats of different groups $(*=$ significant change; $\mathrm{p}$ value $<0.05)$ relative to group $1, . \#=$ significant change; $p$ value $<0.05$ relative to group 2 ).

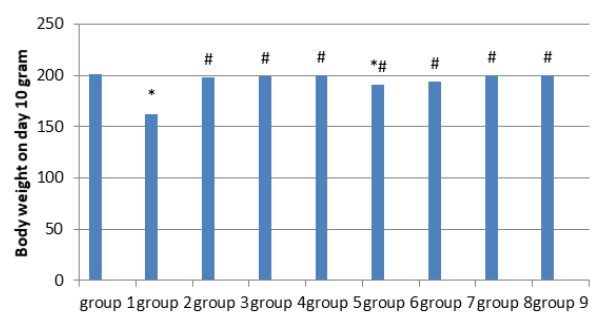

Fig 1: The mean body weight in groups of rats.

\begin{tabular}{|l|l|}
\hline Group & $\begin{array}{l}\text { Rectal } \\
\text { Bleeding } \\
\text { score }\end{array}$ \\
\hline Normal Group 1 & $0.0 \pm 0.0$ \\
\hline Acetic acid model Group 2 & $2.3 \pm 0.5 *$ \\
\hline $\begin{array}{l}\text { Low dose Naltrexone Group 3 } \\
\text { ( 0.05 mg) }\end{array}$ & $0.0 \pm 0.0$ \\
\hline $\begin{array}{l}\text { Medium dose Naltrexon Group 4 } \\
\text { ( 0.5 mg) }\end{array}$ & $0.0 \pm 0.0$ \\
\hline $\begin{array}{l}\text { Hihg dose Naltrexon Group 5 } \\
\text { ( 1 mg ) }\end{array}$ & $0.0 \pm 0.0$ \\
\hline Acetic acid+ Sulfasalazine Group 6 & $0.2 \pm 0.4 \#$ \\
\hline $\begin{array}{l}\text { A. acid+ sulf+Low dose Naltrexon } \\
\text { Group 7 }\end{array}$ & $0.2 \pm 0.4 \#$ \\
\hline $\begin{array}{l}\text { A.acid+ sulf +medium dose } \\
\text { Naltrexon Group 8 }\end{array}$ & $0.2 \pm 0.4 \#$ \\
\hline $\begin{array}{l}\text { A.acid+Sulf+high dose Naltrexone } \\
\text { Group 9 }\end{array}$ & $0.2 \pm 0.4 \#$ \\
\hline
\end{tabular}

Table 2: The score of blood in stool in rats of various groups (Mean $\pm \mathrm{SE}$ ). (* =significant change; $\mathrm{p}$ value $<0.05)$ relative to group 1, . \# = significant change; $p$ value $<0.05$ relative to group 2 ).

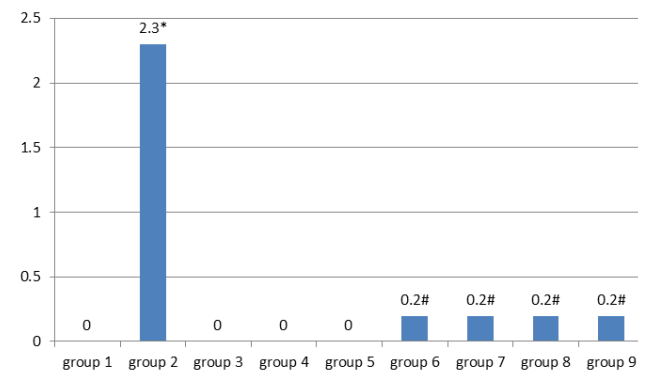

Fig 2: The mean score of the blood in stool in studied groups.

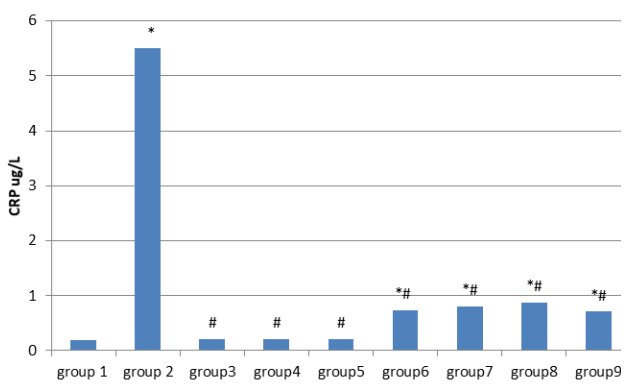

Fig 3: The mean of serum levels of CRP in studied groups. 


\begin{tabular}{|l|l|}
\hline 'Group & CRP \\
\hline Normal Group 1 & $0.19 \pm 0.02$ \\
\hline Acetic acid model Group 2 & $5.55 \pm 0.51^{*}$ \\
\hline $\begin{array}{l}\text { Low dose Naltrexone } \\
\text { Group 3 (0.05mg) }\end{array}$ & $0.21 \pm 0.05$ \\
\hline $\begin{array}{l}\text { Medium dose Naltrexon } \\
\text { Group 4 (0.5mg) }\end{array}$ & $0.21 \pm 0.05$ \\
\hline $\begin{array}{l}\text { Hihg dose Naltrexon } \\
\text { Group 5 (1mg) }\end{array}$ & $0.21 \pm 0.05$ \\
\hline $\begin{array}{l}\text { Acetic acid+ Sulfasalazine } \\
\text { Group 6 }\end{array}$ & $0.73 \pm 0.12^{* \#}$ \\
\hline $\begin{array}{l}\text { A. acid+ sulf+Low dose } \\
\text { Naltrexon Group 7 }\end{array}$ & $0.81 \pm 0.13^{* \#}$ \\
\hline $\begin{array}{l}\text { A.acid+ sulf+ medium dose } \\
\text { Naltrexon Group 8 }\end{array}$ & $0.87 \pm 0.15^{* \#}$ \\
\hline $\begin{array}{l}\text { A.acid+ Sulf+ high dose } \\
\text { Naltrexone Group 9 }\end{array}$ & $0.71 \pm 0.11^{* \#}$ \\
\hline
\end{tabular}

Table 3: The serum levels of CRP ( $\mu \mathrm{g} / \mathrm{L})$ in rats of various groups (Mean $\pm \mathrm{SE}$ ). ( $*$ =significant change; $p$ value $<0.05)$ relative to group $1, \ldots \#=$ significant change; $\mathrm{p}$ value $<0.05$ relative to group 2 ).

\begin{tabular}{|l|l|}
\hline Group & TNF $\alpha$ \\
\hline Normal Group 1 & $32.5 \pm 5.6$ \\
\hline Acetic acid model Group 2 & $\begin{array}{l}599.8 \pm 88.6 \\
*\end{array}$ \\
\hline $\begin{array}{l}\text { Low dose Naltrexone Group 3 } \\
(0.05 \mathrm{mg})\end{array}$ & $30.2 \pm 3.5 \#$ \\
\hline $\begin{array}{l}\text { Medium dose Naltrexon Group } 4 \\
(0.5 \mathrm{mg})\end{array}$ & $33.2 \pm 5.6 \#$ \\
\hline High dose Naltrexon Group 5 (1mg) & $30.8 \pm 3.4 \#$ \\
\hline Acetic acid+ Sulfasalazine Group 6 & $69.8 \pm 5.3^{*} \#$ \\
\hline $\begin{array}{l}\text { A. acid+ sulf+Low dose Naltrexon } \\
\text { Group 7 }\end{array}$ & $73.5 \pm 8.9^{* \#}$ \\
\hline $\begin{array}{l}\text { A.acid+ sulf +medium dose } \\
\text { Naltrexon Group 8 }\end{array}$ & $92.5 \pm 6.7^{* \#}$ \\
\hline $\begin{array}{l}\text { A.acid+Sulf+high dose Naltrexone } \\
\text { Group 9 }\end{array}$ & $67.5 \pm 6.7^{* \#}$ \\
\hline
\end{tabular}

Table 4: The serum levels of $\mathrm{TNF} \alpha(\mathrm{pg} / \mathrm{ml})$ in rats of various groups (Mean $\pm S E$ ). $\left(^{*}=\right.$ significant change; $p$ value $<0.05)$ relative to group 1, . $=$ significant change; $p$ value $<0.05$ relative to group 2 ).

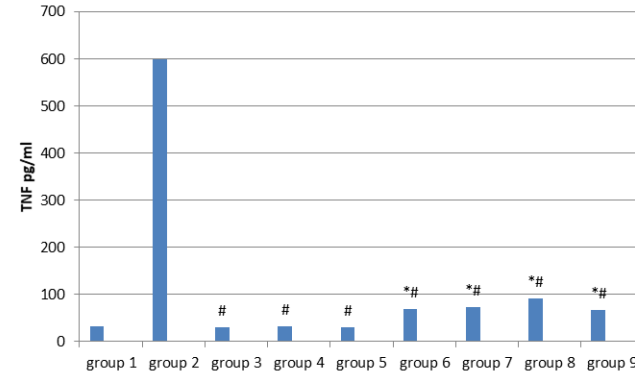

Fig 4: The mean of serum levels of TNF in studied groups.

\begin{tabular}{|l|l|}
\hline Group & $\begin{array}{l}\text { Macroscopic } \\
\text { appearance }\end{array}$ \\
\hline Normal Group 1 & $0.0 \pm 0.0$ \\
\hline Acetic acid model Group 2 & $4.7 \pm 0.8^{*}$ \\
\hline $\begin{array}{l}\text { Low dose Naltrexone } \\
\text { Group 3 (0.05mg) }\end{array}$ & $0.0 \pm 0.0$ \\
\hline $\begin{array}{l}\text { Medium dose Naltrexon } \\
\text { Group 4 (0.5mg) }\end{array}$ & $0.0 \pm 0.0$ \\
\hline $\begin{array}{l}\text { High dose Naltrexon } \\
\text { Group 5 (1mg) }\end{array}$ & $0.0 \pm 0.0$ \\
\hline $\begin{array}{l}\text { Acetic acid+ Sulfasalazine } \\
\text { Group 6 }\end{array}$ & $1.3 \pm 0.5^{* \#}$ \\
\hline $\begin{array}{l}\text { A. acid+ sulf+Low dose } \\
\text { Naltrexon Group 7 }\end{array}$ & $1.7 \pm 0.8^{* \#}$ \\
\hline $\begin{array}{l}\text { A.acid+ sulf +medium dose } \\
\text { Naltrexon Group 8 }\end{array}$ & $1.5 \pm 0.5^{* \#}$ \\
\hline $\begin{array}{l}\text { A.acid+Sulf+high dose } \\
\text { Naltrexone Group 9 }\end{array}$ & $1.3 \pm 0.5^{* \#}$ \\
\hline
\end{tabular}

Table 5: The macroscopic appearance of the intestine of rats in various groups (Mean $\pm \mathrm{SE}$ ). $(*=$ significant change; $\mathrm{p}$ value $<0.05)$ relative to group $1, \ldots \#=$ significant change; $p$ value $<0.05$ relative to group 2 ).

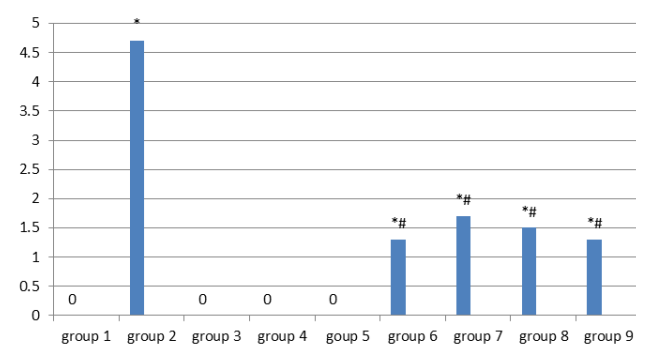

Fig 5: The mean of macroscopical score in studied groups. 

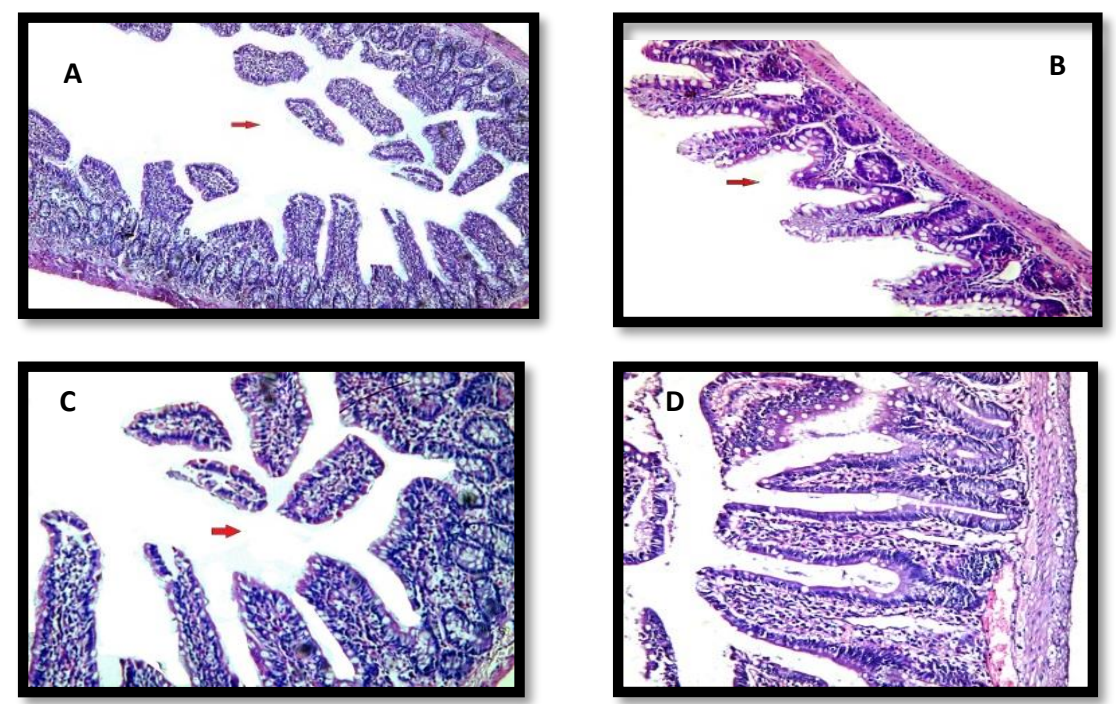

Fig 6: A Photograph of normal control group. (A) Showing the normal villous pattern and architecture of ileal mucosa. (B) Showing the normal appearance of proximal ileum with abundant goblet cells. (C) Showing normal villous pattern and architecture. (D) Showing intact crypts of the epithelial lining with normal villous pattern.
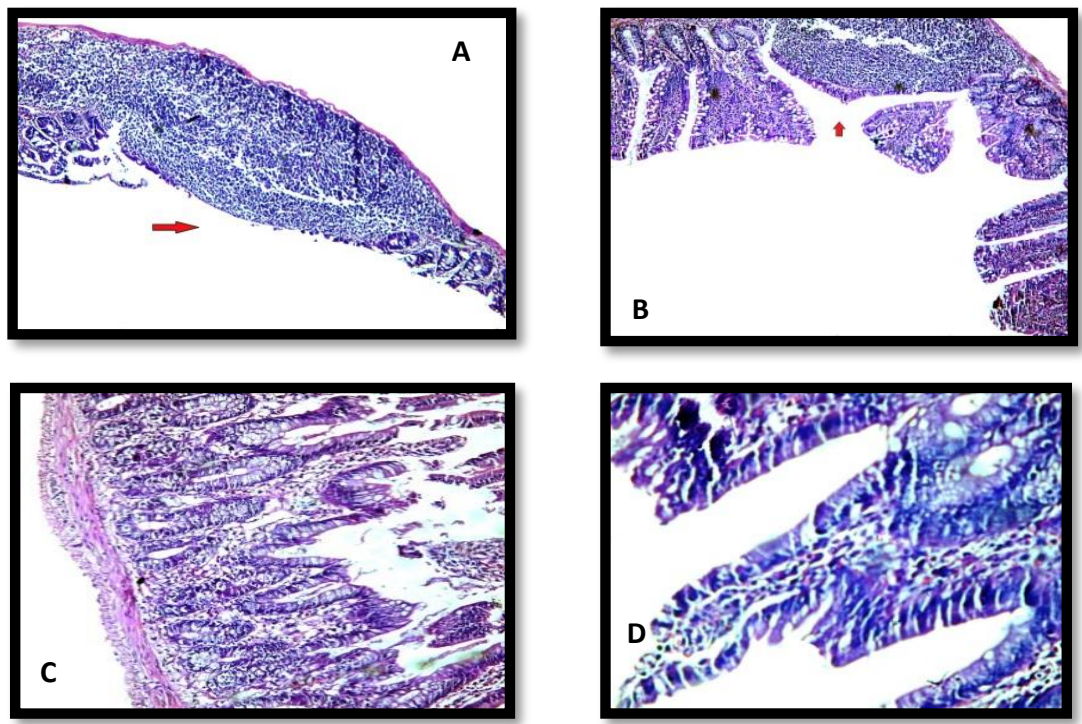

Fig 7: Four photographs of Acetic acid-induced enteritis group (group 2). (A) Showing destruction of epithelium and glands with central ulceration, with underlying dense inflammation. (B) Widening of the villi. (C) Prominent mucosal oedema. (D) Nuclear stratification and loss of goblet cells, typical appearance of intestinal inflammation induced by Acetic acid.
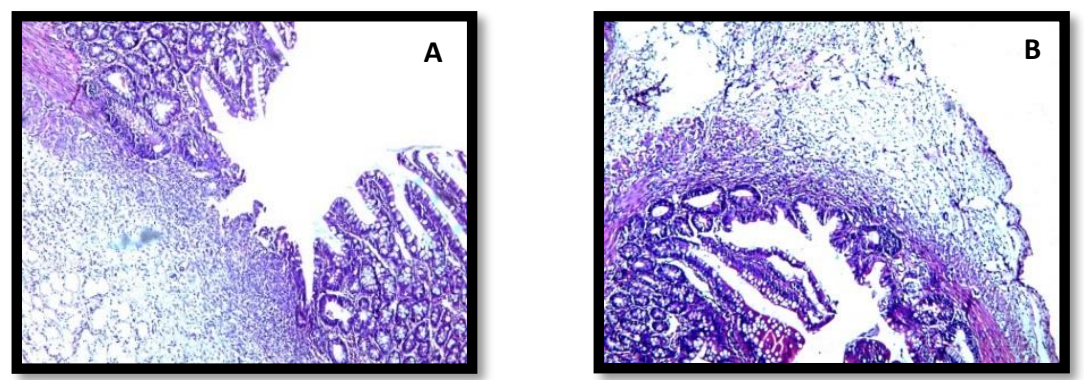

Fig 8: (A), (B): Two photographs show restoration of villous pattern and showing focal marginal mucosal regeneration in sulfasalazine treated group. 

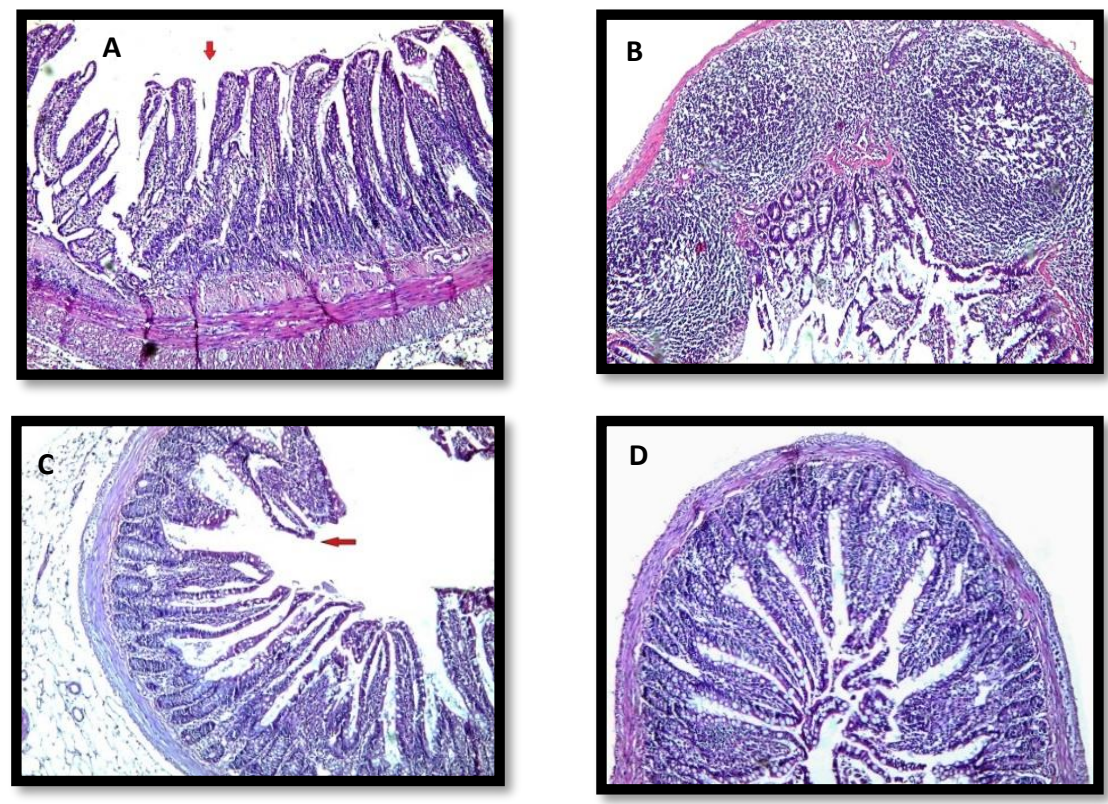

Fig 9: (A) A photograph showing improvement of inflammatory score with regeneration of mucosa and serosal fibrosis in low dose naltrexone treated group. (B) A photograph of high dose naltrexone treated group 8 showed focal regeneration of mucosa. (C) A photograph of the combination sulfasalazine with low dose naltrexone treated group 9 showed regeneration mucosa with improvement of intensity of inflammation. (D) A photograph of the combination sulfasalazine with high dose naltrexone treated group 10 showed regenerated mucosa with retained villous pattern, architecture, and normal goblet cells.

\section{DISCUSSION}

While the precise reason of Crohn's disease remains unclear, evidence indicates a complicated interplay of genetic, microbial, environmental immune, and nonimmune variables.

Several studies have pointed to over-stimulation or insufficient control of the mucosal immune system. Therefore, any medication that can inhibit these immunological and inflammatory effector pathways is likely to enhance the symptoms of patients and reduce inflammatory reactions. ${ }^{17}$

Treatment begins with non-specific suppression of the mucosal immunological response to more specific intervention in the immune cascade as immune modulators. ${ }^{18}$ Therapy with many of these medicines, however, may be correlated with uncommon but dangerous adverse effects, which include lymphoma and opportunistic infections 19,20

In the present study, per rectal injection of acetic acid induced severe intestinal inflammation and deterioration of disease activity indices including progressive weight loss and dark loose stools as indication of intestinal ulceration and bleeding. Furthermore, the lesions were associated with changes in biochemical parameters which included a substantial rise in the level of CRP, TNF- $\alpha$.

Pathological findings are more apparent in distal jejunum and proximal ileum, including mucosal oedema, hemorrhage and necrosis. Morphological and biochemical changes were parallel to histopathological results that showed increased inflammatory cell infiltration, hemorrhage areas, and tissue necrosis with marked deterioration in pathological scores. Lesions occur primarily on the mesenteric side of the distal small intestine as longitudinal ulcers with varying degrees of inflammation and necrosis that are visible in all layers of the intestinal wall.

These results may be due to depletion of Prostaglandins (PG) plays a major role in the pathogenesis of inflammation caused by acetic acid, ulcers, and increased intestinal permeability, allowing luminal contents, like bacterial components, to invade the intestinal wall, causing inflammation. This is in consensus with Stadnicki et al. ${ }^{21}$ who demonstrated the function of proinflammatory cytokines in starting and preservation of intestinal inflammation caused by the acute phase of acetic acid and in a proven model of Crohn's disease. One of the mechanisms of intestinal inflammation caused by acetic acid is oxidative stress. ${ }^{21}$

With the villus tip cells, free radicals induce damage and mitochondrial malfunction in the enterocytes. In the intestinal brush border membranes, oxidative stress has contributed to functional and structural degradation in these membranes. ${ }^{22}$

The present study showed that treatment of acetic acid-induced enteritis with Sulfasalazine administration for 10 days at a dosage of $500 \mathrm{mg} / \mathrm{kg}$ started from day 1 of acetic acid administration showed significant improvement in all parameter; disease activity index, weight loss, frequency of diarrhea, rectal bleeding, increased serum levels of 
TNF $\alpha$ and CRP and improvement in the gross and histopathological scores.

Sulfasalazine can partially induce improvement in inflammatory diseases by blocking the development of Mediators of inflammation. By blocking the activity of cyclooxygenase and lipoxygenase, 5-ASA may decrease inflammation. Its ability to inhibit the formation and/or scavenging of neutrophil reactive oxygen metabolites and to minimise infiltration of neutrophils may also help to suppress inflammation. ${ }^{23}$

These results are in agreement with Lim and Hanauer, ${ }^{24}$ who reported that in patients with crohn's disease, sulfasalazine caused substantial remission relative to placebo. Prakash et al. ${ }^{25}$ demonstrated a substantial decrease in neutrophil infiltration and mucosal inflammation following therapy with salfasalazine, a rat model of Crohn's disease.

In the present study, animals with acetic acid-induced enteritis, which received Naltrexone in different doses for 10 days showed significant amelioration in DAI, significant reduction increased serum TNF $\alpha$ and CRP levels. Moreover, there was significantly improvement in the gross and histopathological scores.

Naltrexone's ability to reverse inflammation and reduce disease activity may be due to its narcotic antagonist effect. Naltrexone is a powerful $\mu$-opioid receptor (MOR) inhibitor in the gut that prevents the interaction of opioid receptors with endogenous opioids. ${ }^{26}$

During inflammation, cytokine release has a significant function in the overexpression of MOR mRNA. Tegeder and Geisslinger 27 and Holzer 28 showed that IL-4 regulates the development of MOR mRNA by binding STAT- 6 transcription factors to the promoter of the MOR gene.

Impaired release of $\beta$-endorphin ${ }^{29}$ and overexpression of MOR by the intestinal cells in patients with $\mathrm{CD}^{30}$ indicates that unbalanced ligand/receptor ratio has a direct relationship with the pathogenesis of the disease.

By preventing MOR, Naltrexone can contribute to a compensatory boost in both, opioid receptor number sensitivity ${ }^{31,32}$ and increase the development of endogenous opioids ${ }^{33}$ that activate them to resolve the disengagement and recovery of opioid peptides from their receptors.

Improving the development of endogenous opioids may also trigger an anti-inflammatory response through activation of KOR, which can lead to cytokine down-regulation, expression of chemokine receptors, decreased expression of adhesion molecules, decreased release of TNF. ${ }^{34}$

Naltrexone has an antagonistic impact on non-opioid receptors, such as Toll-like receptor 4 (TLR4) located in macrophages that can inhibit pro- inflammatory cytokines, $\mathrm{P}$, nitric oxide, and excitatory amino acids. ${ }^{36}$.

The results of the current research are consistent with other studies that have established the possible advantage of blocking opioid receptors in Crohn's disease. Rutgeerts et $\mathrm{al}^{37}$, Smith et $\mathrm{al}^{12}$, Jones et $\mathrm{al}^{38}$, Dotan et $\mathrm{al}^{39}$, and Segal et $\mathrm{al}^{40}$ documented the effect of Naltrexone in reversing inflammatory activity and assisting mucosal healing relative to placebo-treated controls in patients with moderate to severe Crohn's disease.

In CD patients who failed or were intolerant to antiTNF $\alpha$ biologic agents, Smith et $\mathrm{al}^{41}$ reported a substantial enhancement with Naltrexone treatment at $4.5 \mathrm{mg}$ daily.

Matters et $\mathrm{al}^{11}$. identified a beneficial effect of Naltrexone in reducing inflammation of the intestinal tract and RNA of the pro-inflammatory cytokines interleukin IL-6 and IL-12 in normal colitis-induced dextran sulphate sodium (DSS) in mice.

The findings of the current research are contrary to Cohen et $\mathrm{al}^{42}$ who stated that narcotic use was associated with worsen DAI and aggravation of the disease. Steven ${ }^{43}$ who stated that the low dose of Naltrexone could make autoimmune disease worse.

In the current research, there was insignificant difference between the results obtained by treatment of the acetic acid induced enteritis model with Naltrexone and those treated with Salfasalazine.

The previous improvement may be due to the effect of endogenous opioid in increase the intestinal transient time ${ }^{44}$. Influence of the azo bond connection in Salfasalazine may also explain this. This azo bond linkage promotes the active secretion of anions and prevents the absorption of sodium chloride through the small intestine in order to underlie the diarrhoeapromoting impact of azo bond linkage compounds. ${ }^{45}$.

The response of excitatory opioids was selectively blocked by small doses of opioid antagonists (through Gs-protein rather than its inhibitory response (through Gi-protein) ${ }^{46}$

These results may give new important opportunities for the development of new therapeutic methods for Crohn's disease treatment. Compared to other immunosuppressive drugs, the fact that the use of Naltrexone, particularly in small doses, has few, if any, adverse effects make it of interest for treatment of CD. It also offers the potential to reduce doses of immune modulating agents if used as combined therapy.

Its oral route of administration includes some of the benefits of Naltrexone treatment, and once daily dosing, especially in adolescents, can improve patient compliance. 
Low doses of Naltrexone will result in a sense of wellbeing and mood change help to minimize stress, decrease depression, and increase healing.

On the other hand, the benefits of Sulfasalazine, depends on the dosage. The larger the dose, the greater the probability of recovering and remission. As the dosage increases, the side effects of Sulfasalazine become more intolerable; nausea, headache, weakness, mouth sores, extreme dizziness, and difficulty breathing can occur. To prevent blood diseases, liver damage, and nerve/muscle issues, folic acid should be taken every day. ${ }^{8}$

\section{CONCLUSION}

The findings of the current research have shown that Naltrexone has the ability to reduce the inflammatory response to acetic acid, which may have protective effects on the mucosa and provide promising tool for Crohn's disease treatment. Considering the beneficial advantage of Naltrexone, especially at low doses, and the absence of any related immunosuppressive side effects from the use of this medication, this therapy may be more preferable than monotherapy to decreased doses of immune modulatory therapy in the combination therapy of Crohn's disease.

\section{REFERENCES}

1. Puylaert J., Van der Zant F, et al. Infectious ileocecitis caused by Yersinia, Campylobacter, and Salmonella: Clinical, radiological and US findings. Eur Radiol.1997; 7: 3-9.

2. Kornbluth A., Sachar D.B. and Salomon P. Crohn's disease. Gastrointestinal and Liver Disease. 1998; 2(87): 1708-34.

3. D'Haens G., Baert F. and Van-Assche G. Early combined immunosuppression or conventional management in patients with newly diagnosed Crohn's disease: an open randomised trial. Lancet. 2008 ;23: 371(9613):660-7.

4. Tsianos E.V., Katsanos K.H. and Tsianos V.E. Role of genetics in the diagnosis and prognosis of Crohn's disease. World J. Gastroenterol. 2012; 14:18(2):105-18.

5. Tierney L. Crohn's disease. Current Medical Diagnosis and Treatment. 2001; 40(8): 638-42.

6. Mackner L., Bickmeier R. and Crandall W. Academic achievement, attendance, and schoolrelated quality of life in pediatric inflammatory bowel disease. J Dev Behav Pediatr. 2012; 33(2):106-11.

7. Panes J., Gomollon F. and Taxonera C. Crohn's disease: a review of current treatment with a focus on biologics. Drugs. 2007; 67(17): 2511-37.

8. Sands B. Crohn's disease. Gastrointestinal and Liver Disease. 2006; 2: 2459-98.

9. Peng X., Mosser D., Adler M., Rogers T., et al. Morphine enhances interleukin-12 and the production of other pro-inflammatory cytokines in mouse peritoneal macrophages. J Leukoc Biol. 2000; 68:723-8.

10. Pol O. and Puig M. Expression of opioid receptors during peripheral inflammation. Curr Top Med Chem. 2004; 61:51- 4.
11. Matters G., Harms J. and McGovern C. The opioid antagonist naltrexone improves murine inflammatory bowel disease. J Immunotoxicol. 2008; 182-9.

12. Smith J. and Bayles D. Postinfectious irritable bowel syndrome: a long-term consequence of bacterial gastroenteritis. J Food Prot. 2007; 70(7): 1762-9.

13. Reagan-Shaw S., Nihal M. and Ahmad N. Dose translation from animal to human studies. The FASEB Journal. 2008; 22 (3): 659-61.

14. Deshmukh C., Pawar A. and Bantal V. Effect of Emblica Officinalis methanolic fruit extract on acetic acid induced enterocolitis in rats. Res. $J$. Med. Plant. 2010; 4: 141-8.

15. Yamada T., Deitch E., Specian R. et al. Mechanisms of acute and chronic intestinal inflammation induced by acetic acid. Inflammation. 1993; 17: 641-62.

16. Melgar S., Agneta K., and Erik M. Acute and chronic colitis in C57BL/6 mice. Am J Physiol Gastrointest Liver Physiol. 2005; 2(654):345-65.

17. Rama D., Hemant K. and Uday C. IL-1 receptor antagonist (IL-1Ra) gene polymerphism in patient with inflammatory bowel disease in India. Scand J Gastroenterol. 2005; 40: 827-31.

18. Lewis J. An open-label trial of the PPAR- $\gamma$ ligand rosiglitazone for active ulcerative colitis. Am J Gastroenterol. 2001; 96: 3323-8.

19. Sandborn W., Colombel J., Enns R., et al. (2005): Natalizumab Induction and Maintenance Therapy for Crohn's Disease. New England Journal of Medicin. 2005;353 (18): 1912-25.

20. Toruner M., Loftus E. and Harmsen W. Risk factors for opportunistic infections in patients with inflammatory bowel disease. Gastroenterology. 2008; 134: 929-36.

21. Stadnicki A., Sartor R. and Janardham R. Colman Kallikrein-kininogen system activation and bradykinin (B2) receptors in indomethacin induced enterocolitis in genetically susceptible Lewis rats. Gut. 1998; 43: 365-74.

22. Loftus E. Clinical epidemiology of inflammatory bowel disease: incidence, prevalence, and environmental influences. Gastroenterology. 2004; 126: 1504-17.

23. Sandborn W. and Hanauer S. The pharmacokinetic profiles of oral mesalazine formulations used in the management of ulcerative colitis. Aliment Pharmacol Ther. 2003; 17: 29-42.

24. Lim W.C. and Hanauer S. Aminosalicylates for induction of remission or response in Crohn's disease. Cochrane Database Syst Rev. 2010; 88:70-9.

25. Prakash O., Medhi B., Saikia U. et al. Effect of combination of thalidomide and salfasalazine in experimentally induced inflammatory bowel disease in rats. Indian Journal of Experimental Biology. 2011; 49: 672-8.

26. Townsend D., Portoghese P. and Brown D. Characterization of specific opioid binding sites in neural membranes from the myenteric plexus of porcine small intestine. $J$ Pharmacol Exp Ther. 2004; 308: 385-93.

27. Tegeder I. and Geisslinger G. Opioids as modulators of cell death and survival—unraveling 
mechanisms and revealing new indications. Pharmacol Rev. 2004; 56: 351-69.

28. Holzer P. Opioid receptors in the gastrointestinal tract. Regulatory Peptides. 2009; 155(1): 11-7.

29. Kraus J., Borner C. and Giannini E. Regulation of mu-opioid receptor gene transcription by interleukin-4 and influence of an allelic variation within a STAT6 transcription factor binding site. J Biol Chem. 2001; 21: 43901-8.

30. Philippe D., Dubuquoy L., Groux H., et al. Antiinflammatory properties of the mu opioid receptor support its use in the treatment of colon inflammation. Journal of Clinical Investigation. 2003; 111(9): 1329-38.

31. Bostwick J. M. Internet Sex Addiction Treated with Naltrexone. New England Journal of Medicine. 2008; 34 (7): 15-20.

32. Donahue R., McLaughlin P. and Zagon I. Cell proliferation of human ovarian cancer is regulated by the opioid growth factor-opioid growth factor receptor axis. Am J Physiol Regul Integr Physiol. 2009; 296(6): 16-25.

33. Dan Segal A., John K. and Nilesh C. Low dose naltrexone for induction of remission in Crohn's disease. Functional Bowel Disorders. 2013; 28 : 23-34.

34. Finley M., Happel C., Kaminsky D, et al. Opioid and nociceptin receptors regulate cytokine and cytokine receptor expression. Cell Immunol. 2008; 252(1-2):146-54.

35. Brown N. and Panksepp J. Low-dose naltrexone for disease prevention and quality of life. Med Hypotheses. 2008; 72(3):333-7.

36. Jarred Y., Luke P. and David M. The use of lowdose naltrexone (LDN) as a novel antiinflammatory treatment for chronic pain. Clin Rheumatol. 2014; 33(4): 451-9.

37. Rutgeerts P., Diamond R. and Bala M. Scheduled maintenance treatment with infliximab is superior to episodic treatment for the healing of mucosal ulceration associated with Crohn's disease. Gastrointest Endosc. 2006; 63:433-42.

38. Jones J., Loftus E. and Panaccione R. Relationships between disease activity and serum and fecal biomarkers in patients with Crohn's disease. Clin Gastroenterol Hepatol. 2008; 6:1218-24.

39. Dotan I., Rachmilewitz D. and Schreiber S. A randomised placebo-controlled multicentre trial of intravenous semapimod $\mathrm{HCl}$ for moderate to severe Crohn's disease. Gut. 2010; 59: 760-6.

40. Segal D., Macdonald J. and Chande N. Low dose naltrexone for induction of remission in Crohn's disease. The Cochrane database of systematic reviews. 2014; 2: 234-45.

41. Smith J., Field D., Bingaman S., et al. Safety and tolerability of low-dose naltrexone therapy in children with moderate to severe Crohn's disease: a pilot study. J Clin Gastroenterol. 2013; 47(4): 339-45.

42. Cohen L.B. Disappearance of Crohn's ulcers in the terminal ileum after thalidomide therapy. Can $J$ Gastroenterol. 2004; 18(2): 101-4.

43. Steven N. Low Dose Naltrexone. Science-Based Medicine. 2010; 2(8): 445-8.

44. Samways D. and Henderson G. Opioid elevation of intracellular free calcium: possible mechanisms and physiological relevance. Cell Signal. 2006; 18(2):151-1.

45. Keri A., Stephan R. and Jerrold R. Comparative Analysis of the In Vitro Prosecretory Effects of Balsalazide, Sulfasalazine, Olsalazine and Mesalamine in Rabbit Distal Ileum. Inflamm Bowel Dis. 2005; 11: 253-7.

46. Shen K. Antagonists of excitatory opioid receptor functions enhance morphine's analgesic potency and attenuate opioid tolerance/dependence liability. Pain. 2000; 84(2-3):121-31. 